\title{
It takes two to dance: Institutional dynamics and climate-related financial policies
}

Moritz Baer, Emanuele Campiglio and Jérôme Deyris

April 2021

Centre for Climate Change Economics and Policy Working Paper No. 384 ISSN 2515-5709 (Online)

Grantham Research Institute on Climate Change and the Environment Working Paper No. 356 ISSN 2515-5717 (Online) 
The Centre for Climate Change Economics and Policy (CCCEP) was established by the University of Leeds and the London School of Economics and Political Science in 2008 to advance public and private action on climate change through innovative, rigorous research. The Centre is funded by the UK Economic and Social Research Council. Its third phase started in October 2018 with seven projects:

1. Low-carbon, climate-resilient cities

2. Sustainable infrastructure finance

3. Low-carbon industrial strategies in challenging contexts

4. Integrating climate and development policies for 'climate compatible development'

5. Competitiveness in the low-carbon economy

6. Incentives for behaviour change

7. Climate information for adaptation

More information about CCCEP is available at www.cccep.ac.uk

The Grantham Research Institute on Climate Change and the Environment was established by the London School of Economics and Political Science in 2008 to bring together international expertise on economics, finance, geography, the environment, international development and political economy to create a world-leading centre for policy-relevant research and training. The Institute is funded by the Grantham Foundation for the Protection of the Environment and a number of other sources. It has 11 broad research areas:

1. Climate change adaptation and resilience

2. Climate change governance, legislation and litigation

3. Environmental behaviour

4. Environmental economic theory

5. Environmental policy evaluation

6. International climate politics

7. Science and impacts of climate change

8. Sustainable finance

9. Sustainable natural resources

10. Transition to zero emissions growth

11. UK national and local climate policies

More information about the Grantham Research Institute is available at www.Ise.ac.uk/Granthamlnstitute

\section{Suggested citation:}

Baer M, Campiglio C and Deyris J (2021) It takes two to dance: Institutional dynamics and climate-related financial policies. Centre for Climate Change Economics and Policy Working Paper 384/Grantham Research Institute on Climate Change and the Environment Working Paper 356. London: London School of Economics and Political Science

This working paper is intended to stimulate discussion within the research community and among users of research, and its content may have been submitted for publication in academic journals. It has been reviewed by at least one internal referee before publication. The views expressed in this paper represent those of the authors and do not necessarily represent those of the host institutions or funders. 
It takes two to dance: Institutional dynamics and climate-related financial policies ${ }^{1}$

\author{
Moritz Baer $^{1}$, Emanuele Campiglio ${ }^{2,3}$, Jérôme Deyris ${ }^{4}$ \\ ${ }^{1}$ University of Oxford \\ ${ }^{2}$ University of Bologna \\ ${ }^{3}$ RFF-CMCC European Institute on Economics and the Environment \\ ${ }^{4}$ University Paris Nanterre
}

\begin{abstract}
This article studies how institutional dynamics might affect the implementation of climaterelated financial policies. First, we propose a three-dimensional framework to distinguish: i) motives for policy implementation (prudential or promotional); ii) policy instruments (informational, incentive or coercive); and iii) implementing authorities (political or delegated). Second, we use this framework to show how sustainable financial interventions in certain jurisdictions - most notably, Europe - rely solely on informational policies to achieve both promotional and prudential objectives. Policymakers in other jurisdictions - e.g., China also implement incentive or coercive financial policies to achieve promotional objectives. Third, we identify two main institutional explanations for this European 'promotional gap': i) limited control of political authorities on financial dynamics; and ii) strong powers and independence of delegated authorities. This governance configuration leads to an institutional deadlock in which only measures fitting with both political and delegated authorities' objectives can be implemented. Finally, we discuss the scenarios that might originate from the current institutional setting. We identify three possible evolutionary paths: i) a drift towards a green financial technocracy; ii) a re-politicization of delegated authorities; iii) a move towards fiscal-monetary coordination.
\end{abstract}

Keywords: sustainable finance; climate change; low-carbon transition; central banks; financial supervisors; delegation

JEL codes: E44, E58, G28, G18, G14

\footnotetext{
${ }^{1}$ The research leading to these results has received funding from the European Research Council (ERC) under the European Union's Horizon 2020 Research and Innovation Programme (Grant agreement No. 853050). Emanuele Campiglio also acknowledges support from the ESRC through the Centre for Climate Change Economics and Policy, and the Grantham Foundation for the Protection of the Environment. The authors are thankful to Paola D'Orazio, Maxime Duval, Robert Falkner, Sophie Harnay Jens van't Klooster, Mathias Lund Larsen, Andrew McConnell, Richard Perkins, Lilit Popoyan, Christopher Schroeder, Laurence Scialom and Le-Yin Zhang, for their insightful comments on previous versions of the article. Corresponding author: emanuele.campiglio@unibo.it.
} 
In 2017, the EU Commissioner Valdis Dombrovskis expressed his support to the idea of introducing a 'green supporting factor' in bank capital requirements to incentivize lending to sustainable activities (Dombrovskis, 2017). The following year, the European Commission included the idea of 'incorporating sustainability in prudential requirements' in its sustainable finance action plan (EC, 2018). This position was generally greeted with skepticism by most central bankers and financial supervisors (see, among others: Dankert et al., 2018; Elderson, 2018; Rehn, 2018). It was emphasized that the aim of prudential rules is to mitigate financial risk, not to steer private credit in any particular direction. According to central bankers and financial supervisors, capital requirements should not discriminate between green and dirty financial assets, unless clear evidence of risk differentials is available.

This recent clash between public institutions raises deeper questions. For what purposes should banking and financial regulation be used? And who should decide what the admissible purposes are? It appears that, at least for now, EU banking regulation cannot be employed as a policy tool to actively reallocate private financial resources towards sustainable investments. It is, however, allowed to nudge financial institution to assessing their exposure to climaterelated risks and disclosing results to the rest of the market (NGFS, 2019; TCFD, 2017). Other high-income western economies (other European countries, US, Australia) exhibit similar institutional traits. In several emerging economies banking and financial regulation is instead actively used to promote specific productive sectors, including renewable energy and other sustainable sectors (D’Orazio \& Popoyan, 2019). Financial risk is still monitored, but stronger weight is given to development (e.g., green) objectives.

The first objective of this article is thus to explain the observed heterogeneity in institutional behaviors in the field of climate-related financial policies ${ }^{2}$. To do so, we first develop a threedimensional framework to distinguish: i) motives for policy implementation (promotional or prudential); ii) policy instruments (informational, incentive or coercive); and iii) implementing authorities (political or delegated). We then apply this framework to climate-related financial policies in Europe. We show that these policies are mostly - if not exclusively - based on informational measures, to achieve both prudential and promotional purposes. Incentive and coercive policies with promotional purposes are absent. We term this restricted usage of climate-related financial policies for promotional purposes in Europe a 'promotional gap'. We explain this with two main institutional dimensions: i) the low strength of public control on private financial markets; and ii) the high degree of independence of delegated authorities. The specific configurations these dimensions take in Europe only allow for the implementation of consensual informational policies and prevent the implementation of far-reaching promotional policies.

Our second objective is to explore the possible institutional evolutions of the current promotional gridlock in Europe. We identify three main stylized scenarios. First, delegated authorities can gradually move towards more promotional measures without an underlying

\footnotetext{
${ }^{2}$ We focus on public policies targeting private financial institutions, abstracting from the role of public finance.
} 
adjustment of their mandate. We observe signs of a similar promotional trend in recent documents and speeches by European financial regulators. If brought to its extreme, the drift might lead to a technocratic scenario characterized by an agency defining development objectives without political control. Second, political authorities can decide to regain control of certain policy functions (e.g., banking regulation) and use them to achieve their development objectives (e.g., a low-carbon transition). This scenario is similar to the current state of several emerging economies. It might improve the effectiveness of climate financial action, but it also raises concerns regarding the credibility of delegated authorities. A loss of credibility by central banks could be endangering their ability to achieve their primary objectives. Third, a coordinated promotional-prudential policy approach can be developed, with each institution contributing to climate action, while respecting their current institutional boundaries: political authorities engaging in promotional policies aimed at stabilizing climate change, and delegated authorities ensuring financial stability through prudential action.

Our work ${ }^{3}$ contributes to two main strands of literature. First, we provide more solid institutional and governance foundations to the ongoing debate concerning the role of central banks and financial supervisors in addressing climate change and the low-carbon transition (Bolton et al., 2020; Campiglio et al., 2018; Krogstrup \& Oman, 2019). Second, we contribute to the literature on the evolving institutional nature of central banking and financial regulation in the aftermath of the global financial crisis (Baker, 2013; Fontan, 2016; Mabbett \& Schelkle, 2019; Schmidt, 2016), by applying its concepts to the issue of climate change and environmental sustainability.

The remainder of the article is structured as follows. Section 2 presents our three-dimensional framework to categorize climate-related financial interventions. Section 3 examines existing approaches to climate-related financial policymaking and identifies a 'promotional gap' in Europe. Section 4 argues that two institutional features, namely a weaker control on financial dynamics and delegated authorities' stronger independence, can contribute to explaining the European setting. Section 5 examines the resulting policy gridlock and discusses how this prevents the implementation of more ambitious promotional policies. Section 6 explores possible institutional scenarios stemming from the present situation. Section 7 concludes.

II. Setting the scene: motives, instruments and players

In this section, we present our theoretical framework. This allows us to classify climate-related financial policies along three different dimensions: motive, instrument and implementing authority.

\subsection{Promotional and prudential motives}

We identify two main motives behind the implementation of climate-related financial policies.

\footnotetext{
${ }^{3}$ The research relies on written documents (official documents, reports, conference interventions, speeches by policy-makers); direct engagement with stakeholders (semi-structured interviews and private correspondence); and the academic literature.
} 
First, public intervention could be motivated by the desire of tackling climate change by directly influencing the allocation of financial capital. This is what we define as the promotional motive. One of the objectives stated in the Paris Agreement is to 'make finance flows consistent with a pathway towards low greenhouse gas emissions and climate-resilient development' (UNFCCC, 2016). Climate-related promotional financial policies can be conducted to overcome the obstacles preventing larger sustainable financial flows and to bridge the 'green investment gap' arising from the deficit of private financing to fund sustainable activities (Campiglio, 2016). They are therefore based on a 'market shaping' approach (Mazzucato, 2016) and respond to development strategies defined by political authorities.

Second, policies could be motivated by the desire to ensure the stability of the financial system in the face of climate-related challenges. This is what we define as the prudential motive. Several climate-related risks (CRRs) could threaten financial systems and require the implementation of mitigation policies. Since Carney (2015), the literature traditionally distinguishes three categories: physical risks; transition risks; and liability risks. Physical risks refer to the direct or indirect effects of physical events triggered or exacerbated by climate change (e.g. rising temperatures, extreme weather events, disruptions in international supply chains), which could negatively affect business and, through them, insurance companies and the banking system (Batten, 2018). Transition risks refer to the implications of rapidly shifting towards a low-carbon economy, such as the stranding of natural, physical and financial assets (Caldecott, 2018; van der Ploeg \& Rezai, 2020). Finally, liability risks refer to the financial losses that could be incurred as a result of legal actions against companies and regulators for their inaction to tackle climate change. CRRs could trigger ripple effects via production and financial networks (Roncoroni et al., 2021; Baer, 2020; Cahen-Fourot et al., 2021) and have larger macroeconomic impacts, possibly leading to systemic disruptions sometimes referred to as a 'Green Swan' (Bolton et al., 2020). Acknowledging this, prudential-motivated policies are aimed at identifying, monitoring and mitigating these climate-related risks in order to ensure financial stability.

To sum up, promotional policies are mainly aimed at protecting climate stability from financerelated challenges (e.g., obstacles to low-carbon investing). Prudential policies are instead aimed at protecting financial stability from climate-related risks. The boundary between these two types of objectives is often porous. It is reasonable to expect prudential policies to have some kind of promotional consequence. Likewise, promotional policies will probably have some impact on individual and aggregate levels of financial risks.

\subsection{Informative, incentive and coercive policies}

Policymakers have multiple tools at their disposal to achieve those two objectives. They can improve the information communicated to agents (e.g., awareness campaigns on carbon emissions), modify the incentives structure in which they make their decisions (e.g., fiscal policy with carbon taxes) or impose quantity constraints by rationing or even prohibiting certain practices (e.g., ban excessively polluting combustion engines). These levers can be activated at multiple levels, from production to consumption of final goods. In this paper, we focus on policies intervening in the financial sphere, i.e., interventions that directly tackle the 
way private financial flows are distributed across economic activities. Since this allocation of capital takes place upstream of physical investment, production and final consumption, such measures allow to act ex ante on future greenhouse gas emissions.

First, regulators can act to improve the quantity and quality of climate-related information available to financial market players and to provide them with a clear shared set of definitions, rules and instruments. We call these informational policies, as their goal is to bridge the market failures stemming from imperfect and asymmetric information. The informational policy toolkit includes the development of better methodologies to assess the exposure to CRRs, the introduction of disclosure incentives or requirements, the setting of standards and benchmarks, the creation of taxonomies, and others. These policies can be implemented for both prudential and promotional motives.

Second, regulators can modify the structure of incentives (i.e., the relative prices) that financial actors face when making investment decisions. We refer to these as incentive policies, as the allocation of capital remains a market prerogative and investors are free to invest in dirty or risky assets, although at a cost. Several policies in the financial regulation toolkits (e.g. capital requirements) can be calibrated so to differentiate the treatment of assets depending on the CRR-exposure of bank loan portfolios (D’Orazio \& Popoyan, 2019). Monetary policy tools can also be adjusted by including CRRs in the evaluation of asset eligibility as part of collateral frameworks or asset purchase programs (Oustry et al., 2020). Such policies can be implemented either to encourage investors to reduce their exposures to CRR risks (prudential reason) or to increase sustainable investments (promotional reason).

Finally, public institutions can intervene directly on the quantity of financial resources allocated to specific productive activities. We call these coercive policies, as these policies impose direct quantitative controls on financial flows rather than adjusting the environment in which individual decisions are made. These include for example policies targeting directly the composition of bank loan portfolios (e.g. sectoral credit quotas), minimum credit floors or maximum credit ceilings for certain sectors (Bezemer et al., 2018). The aim of these policies is usually seen as predominantly promotional. However, they could also be used for a prudential motive (e.g., lowering exposure of banks to industries prone to transition risk by imposing maximum credit ceiling on coal financing).

Informational, incentive and coercive policies form a gradient of public interventions ranging from the most diverted to the most direct ways of steering private capital flows. These three shades of intervention can be used in conjunction with each other, offering policymakers a set of measures to be implemented in the financial sphere, whether for prudential or promotional reasons.

\subsection{Political and delegated authorities}

Policy objectives (promotional or prudential) as well as the instruments to achieve them (informational, incentive, coercive policies) can belong to different authorities. We distinguish two main types of public institutions that can be involved in the design and implementation of climate-related financial policies. 
First, we identify political authorities (PAs) as the public organisms in charge of determining the direction of economic development on behalf of their populations, deciding between competing interests. They include parliaments, governments, ministries and other public institutions able to contribute to the definition of development strategies. All of them enjoy some form of legitimacy, at least temporarily (Schmidt, 2013). PAs are typically in charge of designing and implementing policies with a promotional aim, as these often have distributional and other socio-economic implications. Depending on the underlying governance framework, they might also be more or less involved in designing prudential policies (D'Orazio \& Popoyan, 2020).

Second, we identify delegated authorities (DAs) as autonomous or semi-autonomous organisms with specific mandates given to them by the PAs. Their legitimacy thus lies in the nature and limits of the delegation and specified mandate (input legitimacy) and in their ability to fulfil their mission (output legitimacy) (Scharpf, 1999). Two main DA categories interacting with financial systems can be identified: central banks and financial supervisors. Central banks are typically tasked with the mandate of achieving price stability, but their mandate can also include full employment, exchange rate management and others (Dikau \& Volz, 2021). In the aftermath of the global financial crisis (GFC) several central banks have also become responsible of ensuring the financial stability of the system. Financial supervisors are delegated authorities with diverse mandates and shapes across countries, tasked with protecting consumers, ensuring the solidity of individual institutions or the resilience of the financial system. They are sometimes in charge of supervising specific sectors of financial systems (e.g., banks, securities markets, insurance companies, etc.). DAs are usually involved in determining policies with prudential aims. They are usually required to have a neutral impact on markets so not to distort financial asset pricing, which, in efficient markets, should already incorporate a correct consideration of risk.

The boundaries between PAs and DAs are not always well defined and vary across jurisdictions. In Europe, for instance, there is a relatively clear distinction of institutional responsibilities. The European Commission (European Parliament) and the governments of member states (national parliaments) are the political authorities with executive (legislative) power and legitimacy to carry out development policies. Monetary policy is delegated to national central banks and, for the 19 countries belonging to the Eurozone, the European Central Bank (ECB). Financial supervision is ensured by the existence of both European- and national-level supervisory authorities. Both central banks and financial supervisors in Europe enjoy a significant degree of freedom in achieving their mandates, and do not have to align to political objectives. In other regions the distinction between PAs and DAs is instead less clear, as the overall governance framework is designed to promote political strategies. In such contexts, central banks and financial supervisors are usually compliant with government's directives. 
In this section we examine a selection of climate-related financial policy approaches through the lens of our framework. We find a pronounced dichotomy between i) high-income western regions and ii) emerging economies. In Europe, informational financial policies are the only measures implemented by political and delegated authorities, for either prudential or promotional reasons. By contrast, emerging regions have a more diversified promotional portfolio that includes also incentive and coercive policies. In this sense, we identify a European 'promotional gap', i.e., a restricted usage of the set of conceivable climate-related financial policies to be used for promotional purposes.

\subsection{Climate-related financial policies in Europe}

Most policy efforts on climate-related finance in high-income regions rely on informational measures. We can identify three main categories of instruments: i) clarification of concepts and standards; ii) development of risk assessment methodologies; and iii) disclosure of risk assessment.

First, several initiatives are attempting to create a transparent and common market understanding of what it means to be 'green'. For instance, the European Parliament and the EU Council agreed on a green taxonomy ${ }^{4}$ stating which activities can be labelled as environmentally sustainable economic activities. To be considered as such, an economic activity must contribute substantially to one of the six environmental objectives (e.g., climate mitigation) without significantly harming one of the others (e.g., protection of biodiversity). Such taxonomy represents 'an essential step in supporting the flow of capital into sustainable sectors in need of financing' (EC, 2018). The EU Carbon Emissions Benchmarks Regulation ${ }^{5}$ enforces disclosure requirement for sustainable benchmarks regarding their integration of ESG factors and sets out the conditions to be labelled as 'EU climate transition' or 'Paris-aligned'. The aim of this regulation is to improve the reliability of sustainable benchmarks by reducing greenwashing. Finally, the creation of an EU Green Bonds represents the last step of the Commission's Action Plan in order to 'facilitate channeling more investments into green projects' (EC, 2018). Such labels already exist, but on a private basis for bonds (e.g., Climate Bonds Initiative) or for different financial products. For example, France labels 'GreenFin' the green investments funds that have a predetermined share of green and exclude certain dirty activities ${ }^{6}$.

Second, both private financial institutions and regulators are starting to develop and use methodologies aimed at assessing the exposure to climate-related risks. This applies to the operations of non-financial firms, to the portfolios of financial institutions, and to financial systems as a whole. French supervisors, for instance, developed a modelling framework focusing on the potential disruptions associated to 'disorderly' transition scenarios (Allen et al., 2020), and submitted it to a group of banks and insurance companies to perform a pilot

\footnotetext{
${ }^{4}$ Regulation (EU) 2020/852

${ }^{5}$ EU Regulation 2019/2089

${ }^{6}$ Law n ${ }^{\circ} 2015-992$ (aug 17, 2015) on energy transition and green growth
} 
bottom-up risk assessment (ACPR, 2020). Similar approaches are being adopted by De Nederlandsche Bank (Vermeulen et al., 2019), the Bank of England (BoE, 2019) and the European Central Bank (ECB, 2020). However, despite the rapid advancements, more work is needed to achieve a comprehensive and widely agreed-upon methodological approach to assess climate-related risk exposure.

Third, measures are being taken to facilitate the disclosure of information by financial and nonfinancial firms concerning their exposure to CRRs and their strategies to address them. For instance, the EU Disclosure Regulation ${ }^{7}$ lays down harmonized rules for financial market participants and financial advisers on transparency with regard to their integration of environmental, societal and governance (ESG) risks, including CRRs. The aim of the regulation is to 'reduce information asymmetries in principle-agent relationships with regard to the integration of sustainability risks'. Such efforts to promote transparency and disclosure of climate-related information have proliferated in recent years. At the national level, France led the way in 2015, introducing in its Energy Transition Law an article requiring listed companies and institutional investors to evaluate, report and address their exposure to CCRs on a comply or explain basis (Mason et al., 2016). At the global scale, the Taskforce on Climate-related Financial Disclosure (TCFD), created by the Financial Stability Board, supports the development of climate-related disclosure methods in order to improve the information available to financial investors and facilitate the inclusion of climate-related factors into decision making (TCFD, 2017).

It is worth noticing how these policy initiatives have been conducted by both political and delegated authorities, often in collaboration. For example, the European Banking Authority (EBA) was mandated by the European Commission to develop a technical standard for ESG disclosure and to assess how ESG risks (with a particular focus on CRR) could be included in the regulatory and supervisory framework for credit institutions and investment firms (EBA, 2019). The Commission also requested the European Insurance and Occupational Pension Authority (EIOPA) for an opinion on sustainability within Solvency II, in particular relating to those aspects that concern climate change mitigation. The three European Supervisory Authorities (ESAs) have also been requested to collect evidence of undue short-term pressure from the financial sector on corporations (EC, 2019).

Delegated authorities also took action on their own initiative in recent years. In December 2017, a group of eight central banks and financial regulators created the Network for Greening the Financial System (NGFS). The NGFS's role is to pool efforts in order to propose adequate policies in the sustainable-finance sphere. Its final report 'A call for action: climate change as a source of financial risk' presented six recommendations: integrating CRR into financial stability monitoring and micro-supervision; integrating sustainability factors into ownportfolio management; bridging the data gaps; building awareness and encouraging \& knowledge sharing; achieving consistent climate disclosure; developing a taxonomy of economic activities (NGFS, 2019). The NGFS is also producing numerous publications to

\footnotetext{
${ }^{7}$ EU Regulation 2019/2088
} 
propose climate scenarios to be used by central banks and financial supervisors to test their financial systems against physical and transition risks (NGFS, 2020).

\subsection{Emerging economies and promotional financial policies}

Within our framework, the climate-related financial interventions examined above can be considered as informational policies, whether implemented for prudential or promotional motives. Although Europe can be considered a leader in these policies, several other countries have also begun to implement them (BCBS, 2020). However, relying only on informational measures appears to be more the exception than the rule, as both incentive-based and coercive financial policies have been introduced across the globe for promotional objectives, especially in emerging regions (Campiglio et al., 2018; Dikau \& Ryan-Collins, 2017). For example, the Bank of Japan and the Bank of Lebanon have implemented incentive policies for banks, with the former offering more favorable refinancing terms to banks that lend to sustainable projects and the latter differentiating reserve requirements based on lending to green projects. Other countries have implemented coercive financial policies for promotional motives. For example, the Reserve Bank of India requires banks to allocate $40 \%$ of their credits to priority sectors, including renewable energy. Bank of Bangladesh's 'green floor' obliges its commercial banks to allocate $5 \%$ of their credits to the green sectors.

Yet, the most striking example of comprehensive financial policies for promotional purposes can be found in China. In addition to informational measures, China uses a wide range of measures, implementing a combination of incentive and coercive policies. These measures are mainly incorporated directly into the Macro Prudential Assessment (MPA), a scoring system through which the People's Bank of China ( $\mathrm{PBoC})$ assesses the performance of banks. It is composed of seven categories, in turn defined by aggregating a large number of subdimensions (Zheng, 2018). While several of them are in line with policies being applied in western societies (e.g., capital adequacy ratio), some go well beyond what European regulators would consider as part of the macro-prudential policy toolkit. For instance, one of the seven categories refer to the alignment of banks to the top-down bank credit policy strategies determined by the PBoC. A dimension of the MPA credit policy category concerns the green credit performance of banks ( $\mathrm{PBoC}, 2018)$. The interest rates on banks' deposits at the $\mathrm{PBoC}$ are then differentiated across performance categories, hence making it economically attractive for banks to align with top-down policy objectives. Additional promotional measures complementing the MPA green credit performance assessment include the acceptance at favorable conditions (e.g. lower credit rating requirements) of green bonds as banks' collateral within the PBoC's medium-term loan facility; differentiated reserve requirements (Fungáčová et al., 2016) and the introduction of green-related criteria into the assessing of banks managers' performance. Finally, green window guidance enables central banks to influence market expectations regarding low-carbon investments through their announcements and communication as for the PBoC (Beggs \& Deer, 2019), but also to impose ad nutum quantitative restrictions on financial flows (Petry, 2020a).

In conclusion, if Europe appears to be well advanced in designing climate-related informational financial policies, it seems instead to be lagging behind when it comes to promotional 
interventions. This promotional gap raises doubts on its ability to support a rapid low-carbon transition (Ameli et al., 2020).

IV. Institutional drivers of the promotional gap

In this section, we examine the institutional characteristics that could explain the promotional gap observed in Europe. We identify two main explanatory dimensions: i) the low level of control of EU political authorities over financial dynamics; and ii) the high level of independence and power of EU delegated authorities.

\subsection{Limited public control on financial capital allocation}

Political and delegated authorities have different levels of will and power to act on financial markets allocation. We observe in this area a stark divergence between high-income and emerging regions, consistent with the identified promotional gap.

European economic frameworks place a strong emphasis on market freedom and efficiency. This reflects the traditional framing of markets as the bottom-up institution that better allocates resources to the most productive uses. The process of economic and monetary European integration has contributed to gradually reducing the role of the 'interventionist' state and simultaneously expanding the 'regulatory' state (Majone, 1997). Public interventions, in this context, should be justified by the necessity to address specific 'market failures', rather than engaging in active 'market shaping' activities steering economic activity in specific directions (Mazzucato, 2016). In Europe, as in other high-income economies, regulators are careful to avoid 'distortions' in financial markets, where interaction between market participants seeking profitable investment opportunities and 'market discipline' are expected to lead to the most effective outcome. Creation of credit can be restricted as a whole on the behalf of financial stability to mitigate excessive risks - as currently done via the Basel III rules (BCBS, 2010) but the allocation of credit across sectors and technologies should be left to the autonomous decisions of financial actors. This approach is well rooted into the European Union institutional framework. For instance, Article 127 of the Treaty on the Functioning of the European Union (TFEU) states that the European System of Central Banks 'shall act in accordance with the principle of an open market economy with free competition' (Consolidated version of the Treaty on the Functioning of the European Union, 2012). This free-market perspective logically leads to European regulators being prone to finding solutions 'for the market, by the market' (Carney, 2016), entrusting financial markets to be able to direct flows to low-carbon activities, once the risks are properly understood. In this context, bridging informational gaps is the priority in order to restore market efficiency, 'without the need for detailed or costly regulatory interventions' (Carney, 2015). An additional reason not to create market distortions in the EU as a transnational entity is given by the risk of inadvertently causing a reallocation of resources among member states without the necessary political processes in support. In fact, Monnet (2018) shows that the end of credit allocation policies in Europe was a prerequisite for European integration. Indeed, distributive financial policies were widespread in Europe before 
the 80's, and their demise was key for achieving the convergence of central bank practices necessary for European monetary Union.

On the contrary, emerging economies' regulators usually maintain a higher systemic control of macro-financial dynamics, guiding capital allocation towards specific activities deemed as socially useful. This is particularly true for the governance of the banking system, in which central banks and financial regulators in emerging economies appear to be much more handson than high-income ones (Dikau \& Ryan-Collins, 2017). These credit guidance policies have been associated with a wider set of 'financial repression' policies aimed at taming free financial market forces. This leads to a completely different understanding of promotional interventions in financial dynamics. Instead of being exogenous shocks to be avoided leading to distortions in the free market mechanism, they represent the normal day-to-day functioning of capital allocation. For example, the presence of the Chinese government in the financial network is systemic, as owner of companies and banks and as a top-down creator of new markets (Wang, 2015). The banks are run by the state, with deep entanglements of communist party hierarchies, following the government's strategies to move up in the hierarchy (Gruin, 2016). The same applies to financial markets that are 'politicized' rather than 'marketized', and even to exchanges which are 'government agencies, subordinated to the China Securities Regulatory Commission (CSRC) or the People's Bank of China, and ultimately, the Chinese government' (Petry, 2020a). In contrast to the European free-market approach, this political embeddedness leads to completely different financial system that can be qualified as 'state-capitalist capital markets' (Petry, 2020b). From window guidance to direct control over publicly owned banks and exchanges, Chinese government engages on a day-to-day basis in market shaping through financial capital allocation in order to help achieve its development goals.

\subsection{Independence and powers of delegated authorities}

EU authorities do not seek to influence financial dynamics for fear of causing distortions and inefficiencies. But they also have fewer levers to do so, having delegated both monetary policy and financial supervision to independent authorities with restricted mandates and increasing powers since the global financial crisis.

Central bank independence is a relatively recent phenomenon. The claim that delegating monetary policy functions to independent technical agencies would improve the ability of societies in keeping low and stable inflation was first put forward by academic economists (see for instance Kydland \& Prescott, 1977). These contributions, originating from a period of prolonged high inflation, argued that 'rules', rather than 'discretion', would solve monetary policy time inconsistency issues and protect central banks from the undesired interference by governments and 'political business cycles' (Nordhaus, 1975). Despite the presence of counterarguments (McNamara, 2002), the theory was successful in triggering the rapid diffusion of interventions aimed at making central banks independent during the ' 80 s and ' 90 s (Goodhart, 2010). But this independence shift was particularly salient in market-friendly high-income countries, while most developing economies tend to preserve a higher level of political control over their central banks (Dikau \& Volz, 2021; Dincer \& Eichengreen, 2014). The creation of 
independent specialized agencies in Europe fitted with the governance shift to a rule-making political authority framework (Majone, 1997).

As a counterpart to this greater independence, the mandate of central banks is generally defined narrowly and precisely in order to avoid institutional drift (i.e., to prevent the independent delegated authorities from claiming undue autonomy and powers from the elected political authorities). These delegated authorities must respond to a precise mandate providing them legal input legitimacy, the fulfilment of which is their sole source of output legitimacy. In highincome countries, price stability is usually their only prerogative, but some development objectives may remain: the US Federal Reserve, for example, has a mandate for both price stability and unemployment. In emerging economies, this development/promotional dimension is often more prominent and central banks are granted less restrictive mandates, which is consistent with their higher level of political control. It is the opposite in high-income countries, where delegated authorities play a technical role and have restricted mandates. As a result, mandatory green financial policies and regulations are adopted mainly in jurisdictions characterized by low central bank independence (D’Orazio \& Popoyan, 2020). In Europe, the ECB has a price-stability mandate, its primarily source of output legitimacy being to 'keep inflation close but below 2\%'. This prevents promotional interventions, as ECB's monetary policy follows a 'market neutral' principle, avoiding any kind of distributive choices in its decision, providing liquidity and interests rates without discriminating between economic activities. Taking root in the 'open market principle' of the European Union, the same 'nondistributional' or 'neutral' principle applies to financial regulation. Financial supervisors (from national central banks to new delegated authorities created after the global financial crisis) are requested to adhere to their prudential mandate, using its new discretionary macroprudential tools without distorting private capital allocation or 'picking winners' among economic activities.

Finally, it should be stressed that recent developments in EU financial governance have exacerbated this prudential tendency. Indeed, the cascading effects triggered by the global financial crisis have led to a reshaping of the European institutional framework, placing greater emphasis on the prudential missions of delegated authorities, giving them responsibility for new instruments to govern finance (Baker, 2013; Blinder et al., 2017). In addition to monetary policy and price stability, both the ECB and the $\mathrm{BoE}$ (re)gained explicit control of prudential missions after the global financial crisis. The Single Supervisory Mechanism and the Banking Union allowed the ECB and national CBs to expand their functions to include financial stability and macroprudential regulation, and even fostered the creation of new delegated authorities such as the European Systemic Risk Board and the three ESAs. With a prudential mandate, delegated authorities have been granted control over new unconventional policies such as Quantitative Easing or macroprudential discrete interventions, even though their distributional consequences are unclear (Baker, 2013). This expansion led to higher independence and a reinforced prudential side of their mandate. 
As discussed in the previous section, European jurisdictions are characterized by a weak public control on private financial dynamics and strongly independent delegated authorities. In this section, we unfold how this institutional framework leads to an impasse, preventing the implementation of far-reaching promotional policies. We illustrate this situation with two examples of conflictual policies: a 'green supporting factor' and 'green' monetary policy.

\begin{tabular}{|c|c|c|c|}
\hline & & \multicolumn{2}{|c|}{ Delegated authorities } \\
\hline & & Fits with objectives & Does not fit with objectives \\
\hline \multirow{2}{*}{ 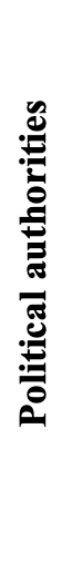 } & $\begin{array}{l}0 \\
: \\
0\end{array}$ & $\begin{array}{l}\text { Disclosure standards; taxonomies; } \\
\text { benchmarks; stress-testing; green } \\
\text { bond standards }\end{array}$ & $\begin{array}{c}\text { Green-supporting factor; other green } \\
\text { prudential policies; green monetary } \\
\text { policies }\end{array}$ \\
\hline & 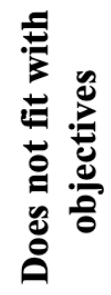 & $\begin{array}{l}\text { Dirty-penalizing factor; sectoral } \\
\text { leverage ceilings; credit controls }\end{array}$ & \\
\hline
\end{tabular}

Table 1 Climate-related financial policy space in Europe

\subsection{Europe's green financial policy space}

The division of powers between two types of authorities is not problematic as long as the policies pursued by one authority have a neutral - or even beneficial - effect on the achievement of the others' objectives. However, this is not always the case. For instance, promotional measures aimed at expanding green financial investments by easing capital requirements could lower safeguards against financial instability. In Europe and similar jurisdictions, delegated authorities have the power to challenge policies that might hinder their mandate, limiting the green finance admissible policy space.

Table 1 tracks two dimensions of the policy sphere: i) what fits (or doesn't fit) with the objectives of political authorities; and ii) what fits (or doesn't fit) with the objectives of delegated authorities. We identify four quadrants.

The top-left quadrant contains all the 'consensual' policies that simultaneously: i) mitigate (or at least do not worsen) exposure to financial risk; and ii) push the financial system in a direction compatible with the development objectives of political authorities. We find in this quadrant all the policies that we observed being implemented essentially in every jurisdiction: disclosure 
requirements, taxonomies, sustainability benchmarks, green bond standards, climate stress test exercises, data sharing, etc. This is, in a nutshell, what the NGFS recommends and works on (NGFS, 2019). These informational measures do not meet with any resistance from either side, as they fit with both promotional and prudential aims. From the prudential perspective, they are considered means to overcome issues related to imperfect and asymmetric information regarding the exposure to CRRs, which prevents financial market players to price assets appropriately and financial regulators to ensure adequate supervision. Improving the production, harmonization and circulation of information between firms, financial institutions and supervisors should help ensuring financial stability. From the promotional perspective, informational policies are considered a means to encourage financial flows towards sustainable activities, while preventing green washing thanks to comparable and harmonized standards. Reducing information asymmetries between savers and asset managers is supposed to allow a better expression of investors' environmental preferences and help climate stabilization.

The top-right quadrant includes conflictual policies that are likely to have a positive impact on the reallocation of financial resources towards sustainable sectors, but do not fit with the restricted mandate of delegated authorities as they have uncertain or negative implications on the exposure to financial risk. This is the case of 'green' prudential or monetary policies, which could be bent to incentivize lending to green sectors even without (or before) solid evidence of risk differentials in their favor. We observe the implementation of these type of policies in emerging economies, but not in Europe and similar jurisdictions. The reason for their absence is that, while being supported by political authorities, these policies face the opposition of delegated authorities concerned about their prudential implications. We explore more in detail two examples of policies in this quadrant in the following section.

The bottom-left quadrant includes conflictual policies that would have a positive impact on the exposure to financial risk but might have contrasting effects on some development objective. For instance, using banking and financial regulation to introduce disincentives to high-carbon investments (e.g., a 'dirty-penalizing factor') might mitigate the exposure to financial risks, but could negatively affect bank credit volumes and economic growth ${ }^{8}$. For this reason, the policies in this quadrant are generally supported by delegated authorities but are not conducted by political authorities.

The institutional setting present in Europe restrains the allowable policy space in green finance to consensual policies (top-left quadrant). Delegated authorities, in charge of preserving price and financial stability, possess the institutional strength and independence to push back conflictual policy initiatives that might put at risk the achievement of their objectives. Emerging economies have instead a wider green financial policy space, since development objectives are given more weight in these jurisdictions. Certain policies are admissible, and often carried out by delegated authorities themselves, even if they could potentially have distributive impacts and/or negative implications in terms of financial risks. One could think of the matrix in Table 1 being partially squeezed for emerging economies, so to reduce the

\footnotetext{
${ }^{8}$ These costs may be exacerbated by the regulatory and cognitive capture of the banking sector (Scialom, 2019).
} 
horizontal axis: the less independence delegated authorities enjoy, the smaller will be the quadrants on the right of the matrix.

\subsection{Delegated authorities' resistance to green financial policies}

In this subsection we analyze more in detail two examples of how policies falling into the topright quadrant of Table 1 have been treated by political and delegated authorities in recent years: i) the proposal of introducing a green supporting factor on bank capital requirements; ii) the proposal of introducing climate-related considerations in the conduct of monetary policy.

As mentioned in section 1, a green-supporting factor (GSF) on bank capital requirements has been proposed in recent years. A GSF would ease the constraints posed by risk-weighted capital ratios that banks need to respect, as required by the EU Capital Requirement Regulation and Directive. Allocating credit to sustainable activities would allow banks to hold less capital for regulatory purposes and hence extend their leverage, with likely positive effects on their profits. It would possibly also counterbalance the undesired perceived adverse effects of existing prudential regulation on long-term green investments (Campiglio et al., 2017). A similar instrument was introduced in 2014 at the EU level to incentivize lending to small and medium-sized enterprises, although the evidence on its effectiveness has been mixed (EBA, 2016). The introduction of a GSF was supported by the European Parliament and the European Commission (Dombrovskis, 2017; EC, 2018). However, the proposal of introducing a GSF did not meet the favor of delegated authorities, as 'the essence of capital requirements is to safeguard financial solidity and stability' (Dankert et al., 2018). The European Commission decided to put the legislative proposal on hold and to mandate the EBA to carry out an expertise mission on the relevance of such an instrument. (See the revised Capital Requirements Regulation (CRR 2); EBA, 2019) Thus, it is now up to a delegated authority with a prudential nature to decide on the implementation of an instrument designed to serve promotional objectives.

A second relevant example of conflictual policy is greening monetary policy, and especially the ongoing 'quantitative easing' programs of purchase of financial assets. The standard approach taken by central banks in Europe and similar jurisdictions is guided by the principle of 'market neutrality'. This consists in buying assets in a way so not to distort the marketdriven allocation of capital; for instance, by allocating purchases across sectors in the same proportion to the sectoral outstanding amounts in corporate bond markets. However, it was argued that respecting existing market composition is actually a non-neutral choice, and that the high carbon intensity of modern financial markets leads central bank interventions to reinforce its high-carbon lock-in (Matikainen et al., 2017; van't Klooster \& Fontan, 2020). The de jure principle of not choosing leads to a de facto choice in favor of polluting activities. The same bias seems to be at work within the ECB's collateral framework, as its haircut regime is very favorable to dirty financial securities and appears not aligned with climate objectives (Dafermos et al., 2020; Oustry et al., 2020). With these conclusions in mind, several contributions have argued for monetary policy to be 'greened' (Monnin, 2018; Schoenmaker, 2021). Two main strategies can be adopted. First, a prudential approach would lead to incorporate adequately assessed CRRs in any monetary operation. Although this would 
probably have some promotional implication, it would not be motivated by promotional motives, but by the desire to monitor and mitigate financial risks. This is the approach that has been promoted in recent years by European delegated authorities; see for instance Lagarde (2020b): 'At the ECB, as part of our strategy review, we will examine the risks posed by climate change and how these risks feed into the monetary policy framework'. Second, a more promotional approach can be adopted, actively discriminating between green and dirty assets without underlying evidence of risk differentials. This promotional strategy is generally not supported by delegated authorities, who see it as possibly negatively affecting the central bank input legitimacy as well as their ability to attain its primary objectives. Weidmann (2020), Governor of the Bundesbank, epitomizes such view, arguing that it is not the task of the Eurosystem to penalize or subsidize certain industries. Correcting market distortions often has intricate distributional implications. Such decisions need strong democratic legitimacy and are a matter for governments and parliaments. They have the right tools at their disposal and, as elected representatives, they also have the democratic authority to use those tools.'

So far, delegated authorities have resisted the implementation of promotional-motivated policies that might hinder their mandate or objectives. However, this situation could change as climate-related issues become more pressing.

VI. Future institutional scenarios

In this final section we adopt a forward-looking perspective to identify the possible evolutions stemming from the current promotional gap. Table 2 provides a stylized game-theoretical setting to help us illustrate them. We assume political authorities to have two main strategies: i) take a strong action to mitigate climate change (e.g., implement a carbon pricing policy in line with climate stabilization objectives); ii) take no or limited climate action. Delegated authorities also have two main strategies: i) continue adhering to market neutrality and prudential motives; ii) adopt policies with promotional aims. These strategies represent the extremes of a continuum of possible behaviors by both PAs and DAs. We identify four main scenarios (1. to 4.) and three main dynamics (a. to c.).

\subsection{The status quo}

We start by analyzing the equilibrium we have been experiencing in recent decades (Scenario 1. Status quo). In this setting, limited action is taken by PAs, as evidenced by the insufficient adoption of carbon pricing initiatives (World Bank, 2020) and DAs limit themselves to the achievement of the objectives stated in their mandate, without overstepping. When they get involved in climate-related issues, they do so by respecting market neutrality and demanding evidence of financial risks before intervening in a 'market distortive' manner.

We argue this equilibrium to be ultimately unstable due to the increasing environmental constraints. As argued in section 5, the only policies that can be implemented to shift financial resources towards sustainable investments are informational ones. While positive, these policies by themselves are unlikely to either fully capture inherently uncertain climate-related risks or to push financial resources towards sustainable activities with the sufficient strength 


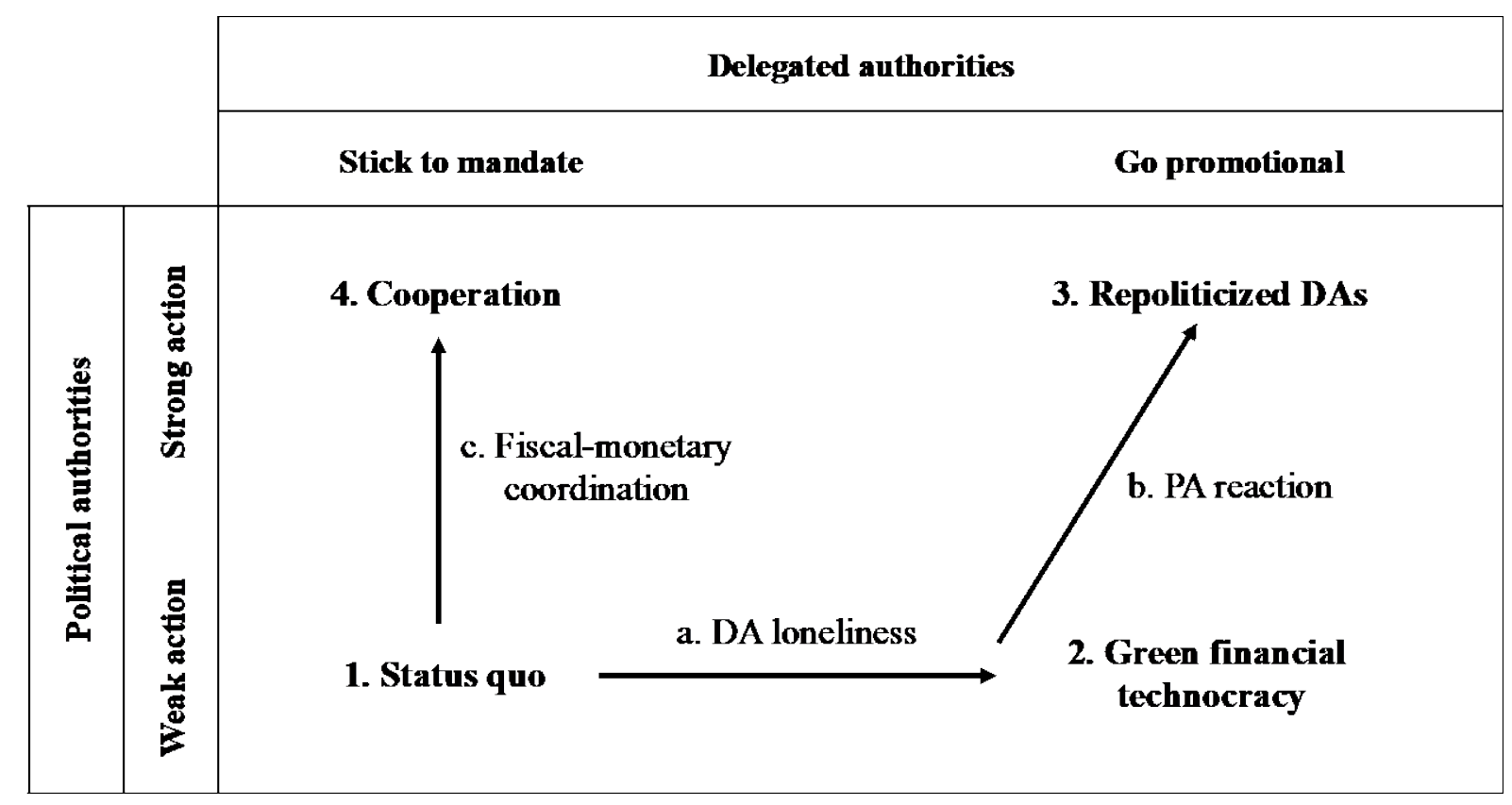

Table 2 Stylized institutional scenarios

(Ameli et al., 2020; Christophers, 2017). A prolonged status quo may lead to a 'too late too sudden' scenario (NGFS, 2020), where the sudden future realization of the necessity of a lowcarbon transition, possibly driven by an unanticipated climate disruption, causes large repercussions to economic and financial stability. To avoid this undesirable scenario, either PAs or DAs need to adopt promotional measures to steer credit in the direction of low-carbon activities.

\subsection{DA loneliness and green financial technocracy}

One first option is for DAs to adopt climate-related promotional policies. Whether and to what extent delegated authorities will go promotional without an explicit ex ante change in their mandate will depend on the relative weight they attach to two sets of factors: i) input legitimacy, institutional credibility and mandate constraints on one side; and ii) output legitimacy and environmental concerns on the other. Some DAs might consider their input institutional legitimacy more important and decide to stick to their prudential-oriented mandates. Other DAs might instead consider climate change likely to jeopardize their primary objectives: besides endangering financial stability with increased physical risks, climate change would disturb monetary policy transmission channels and limit the European central banks' ability to achieve their objective of price stability in the future (Andersson et al., 2020). ECB President Christine Lagarde seems to be of that opinion: 'I contend that price stability can be significantly affected by climate change, and that as a result of that, if we want to deliver on our mandate, we have to be not only mindful but also take action in order to prevent climate change from affecting that price stability that is our mandate' (Lagarde, 2020a).

In a context characterized by political authorities' inaction, this might force DAs to intervene to compensate for the lack of promotional effort in the face of an upfolding climate crisis (dynamics a. DA loneliness). This situation mimics the 'loneliness' of central banks in the 
aftermath of the financial crisis, when the policy gridlock affecting governments' actions forced delegated authorities to become the 'only game in town' and led to unprecedented monetary interventions (Mabbett \& Schelkle, 2019). The longer PAs delay sufficient action, the more likely it is that DAs will step in to compensate for the lack of political will and to avoid irreversible physical risks, using the 'authorization gaps' in their mandate (de Boer \& van't Klooster, 2020). Recent developments suggest that we are already experiencing a gradual move of independent DAs towards promotional policies. These include: the ECB and the BoE setting up dedicated climate-related research groups to inform policy decisions (ECB, 2021); the consideration given to the option of abandoning the market neutrality principle in asset purchase programs (Schnabel, 2020); or the decision by the ECB to invest a proportion of its own funds portfolio in a green bond fund established by the Bank for International Settlements (Lagarde, 2021). This trend is mainly motivated by the concern that climate change might affect price and financial stability, i.e., primary objectives. Promotional interventions to mitigate climate change could therefore be interpreted as an attempt to 'lean against the (climate) wind' (D'Orazio \& Popoyan, 2020), in a same preventive way as macroprudential policies proactively counter the accumulation of risks during the build-up phase.

Delegated authorities could also argue that going promotional is not only a way to achieve their (primary) objectives, but also part of their (secondary) objectives. For example, Article 127 of the Treaty on the Function of the European Union (TFEU) states that the European System of Central Banks (ESCB) 'shall support the general economic policies in the Union with a view to contributing to the achievement of the objectives of the Union' (among which we find protecting and improving the quality of the environment), if this comes '[w]ithout prejudice to the objective of price stability' (Consolidated version of the Treaty on the Functioning of the European Union, 2012). Solana (2019) argues that the central banks are also bound by the Article 11 of the TFEU, which states that '[e]nvironmental protection requirements must be integrated into the definition and implementation of the Union's policies and activities'. The mandate of the ECB, and more in general those of delegated authorities, could thus leave some room to legitimize a certain greening of financial policy actions. In addition, DAs are sometimes explicitly pushed to be more proactive in the climate policy sphere by PAs themselves (see for instance EU Parliament motion 2018/2007(INI) that 'acknowledges the independence of the ECB and its primary mandate as being to preserve price stability but recalls that the ECB as an EU institution is also bound by the Paris Agreement').

Besides, reinterpretations of delegated authorities' mandate are possible, as shown by ECB's actions in the aftermath of the global financial crisis (GFC) (de Boer \& van't Klooster, 2020). Before the GFC and the sovereign bond crisis, the interdiction of monetary financing ${ }^{9}$ of the EU states used to be interpreted in a narrow sense, preventing ECB from buying sovereign debt to close spreads between national bonds. During the sovereign debts crisis, unconventional policies such as Securities Market Programme (SMP), Outright Monetary Transactions (OMT) and Public Sector Asset Purchase Programme (PSPP) led to massive buying of sovereign debts on secondary markets, therefore closing the spreads and de facto and annihilating the disciplinary role of market pricing. Both OMT and PSPP were attacked in justice but confirmed

\footnotetext{
${ }^{9}$ See Article 123 of the Consolidated version of the Treaty on the Functioning of the European Union
} 
ex post as legitimate (see Court of Justice of the European Union's judgments of June 16, 2015 (aff. C-62/14 ${ }^{10}$ ) and October 08, 2018 (aff. C-493/17)). The past successes of the ECB in broadening its actions and reinterpreting its missions could set an important precedent, showing delegated authorities that they can enlarge the spectrum of their actions and engage in the promotional sphere, moving continuously towards a DAs loneliness' outcome, as there is room for 'stealth' institutional drift (Schmidt, 2016).

If brought to its extreme, this trend could lead to the establishment of a climate-friendly technocratic setting (scenario 2. Green financial technocracy), i.e. a situation characterized by independent technical agencies with the power of defining the features of economic and societal development with no or little political control and without an appropriate adjustment of their mandates (Climate Leviathan or Behemoth of sorts, see Wainwright and Mann, 2018 and Fontan, 2016). Letting delegated authorities fully use their authorization gaps without democratic input to legitimate might ultimately put at risk the credibility of these institutions and affect their ability to reach their primary goals (Cochrane, 2020). In addition, promotional DAs may not properly address prudential concerns related to CRRs, possibly allowing or exacerbating a 'disorderly transition'.

\subsection{PA reaction and green central banking}

We argue that the scenario of a green financial technocracy is also inherently unstable. An increasing disconnection between the de jure institutional arrangement and the de facto distribution of financial governance powers is likely to eventually force a reaction from political authorities, who could step in to disavow DA promotional pushes and prevent further agency drift or to offer its political support by legitimizing them ex post (dynamics b. PA reaction).

As delegations were designed and assigned in the past, they can be changed or revoked. In national jurisdictions this can usually be achieved by an act of the Parliament. The case of European institutions is more complex, as their legitimacy is enshrined in international treaties that require long processes to be modified (van't Klooster, 2021). Governments can thus decide to bring back monetary policy and financial regulations under their control. This would allow them, for instance, to differentiate bank capital requirements according to the carbon intensity of lending for purely promotional motives, as the European Commission has already proposed. If such a change would represent a break in the historical trend of increased independence of central banks, Goodhart (2010) argues this movement towards a new regime of central banking characterized by more intrusive regulations, greater government involvement and less confidence in market mechanisms, has already started since the GFC. This setting would see DAs aligning their actions to PAs development objectives, even if they might have negative prudential implications (scenario 3. Re-politicized DAs). This might seem implausible in the European context, but it is very common in other jurisdictions (see section 3), and has been the default institutional setting in Europe for a long period in the past (Monnet, 2018), despite what

\footnotetext{
${ }^{10}$ Articles 72 to 76 of this judgment recognize the legitimacy of the ECB to intervene in an unbalanced way in its asset repurchase when i) the market pricing was unsatisfactory, imposing an 'excessive risk premia'; ii) this undermined the ESCB's monetary policy transmission mechanism.
} 
'institutional amnesia' often suggests (Braun \& Downey, 2020). Several contributions have argued that limiting DA independence could be beneficial to implement effective climate action. However, this could also imply costs, as price and financial stability were delegated to independent authorities to avoid problems of time inconsistency and political capturing. Revoking the delegations could bring these problems back.

Of course, PAs' reaction doesn't have to be that radical. Instead of regaining control of the delegated authorities and abandoning central bank independence, political authorities could grant DAs with new input legitimacy to implement promotional policies. This would lead to an intermediate situation between scenario 2 (Green financial technocracy) and scenario 3 (Repoliticized DAs) as PAs react to the lonely drift of DAs to give them both clearer grounding and boundaries in order to clarify democratically the 'authorization gaps' of their mandates. To achieve this, a mandate change is not necessary, as ordinary legislative procedures (by e.g. clarifying the ranking of the objectives or the statutes of the ECB) could prove sufficient (van't Klooster, 2021). This could also take the form of a legal procedure (similar to the one that followed the programs of the OMT and the PSPP, the European Court) stating ex post about the legitimacy of green promotional policies conducted by DAs and providing them with legal ground. Nevertheless, such a procedure acting retrospectively and emanating from a magistrate rather than from elected authorities would not have the same force, as judicial review does not by itself provide democratic legitimacy (de Boer \& van't Klooster, 2020).

\subsection{Cooperation: It takes two to dance}

Finally, we consider the scenario in which the PA takes action to ensure climate-friendly promotional measures, leaving DAs to continue aiming for prudential objectives (dynamics c. Fiscal-monetary coordination). This is probably the best possible outcome within the current institutional framework, as each authority contributes to a common coordinated objective while maintaining their respective fields of competence and respecting their mandates. To achieve a smooth and rapid low-carbon transition (scenario 4. Cooperation), in the long run, it takes two to dance. Such a cooperation scenario can come in two versions.

In the first version PAs implement credible and strong climate mitigation policies shifting the incentive of market players away from carbon-intensive activities, and DAs closely monitor climate-related financial risks while pushing market players to evaluate and disclose their exposure. This would respect their existing area of institutional responsibility. However, it is unclear how likely strong climate mitigation policies might be in the near future. Ambitious carbon pricing policies have strong immediate economic and political costs making them unpopular (see for instance the gilets jaunes movement in France), leading to insufficient action from political authorities (Maestre-Andrés et al., 2019). This has not been a phenomenon unique to Europe: despite the decade-long discussion on how essential it would be to price carbon, policy initiatives implemented so far at the international level still do not live up to the stated ambitions (World Bank, 2020). In addition, both European national governments and the European Union apparatus appear distracted by a vast range of complex issues (e.g., the Eurozone crisis, Brexit, increasing inequality, migration flows, Covid crisis and others), therefore paying insufficient attention to longer-term objectives as climate mitigation and 
adaptation. The European institutional framework is further complicated because of the presence of multiple veto players among which it is often cumbersome to find an agreement over ambitious climate policies (Tsebelis, 2002).

Due to the obstacles mentioned, it might prove difficult for the government to implement farreaching climate fiscal policy. An alternative strategy to achieve cooperation would be to design and assign an additional delegation linked to the achievement of a carbon price path compatible with emission reduction objective determined by the PAs (Grosjean et al., 2016). The delegation would be entrusted to an independent agency, which could be either positioned within existing central banking institutions (a 'carbon central bank') or constitute a new institution (a 'carbon council'), so to improve the credibility and predictability of policy commitments (Delpla \& Gollier, 2019; G30, 2020).

VII. Conclusions

In 2018, the chair of the NGFS Frank Elderson gave a speech to officially present the Network, meaningfully titled 'Let's dance' (Elderson, 2018). However, as we argue in this article, central bank cannot and should not dance alone. First, in several jurisdictions their ability to introduce promotional financial policies is limited by their own positioning within the institutional framework. Second, if they were to become promotional without being accompanied by their political counterparties, they would risk their legitimacy and credibility. It will take two to actually dance: political and delegated authorities, in coordination.

The aim of this article has been to i) offer institutional explanations to the observed diversity of climate-related financial policies across jurisdictions; and ii) explore scenarios of future institutional evolutions.

After proposing a framework distinguishing policy motives (prudential or promotional), instruments (informational, incentive or coercive), and implementing authorities (political or delegated), we use it to analyze climate-related policies being implemented internationally. While all jurisdictions appear to be developing informational policies justifying them with both prudential and promotional motives, only emerging economies have introduced incentive or coercive financial policies with promotional aims. We explain the 'promotional gap' present in Europe and other similar jurisdictions with two main institutional characteristics: i) a weaker public control on private financial dynamics; and ii) stronger and more independent delegated authorities. These traits limit the European green finance policy space to consensual informational policies. Other promotional financial policies with uncertain prudential implications - such as a green supporting factor or a green monetary policy - have been pushed back by delegated authorities.

We also argue the current status quo is unsustainable due to environmental constraints. At some point, someone will need to introduce stronger promotional policies to steer credit towards sustainable sectors. Given the distribution of responsibilities, missions, and powers crystallized within the current institutional framework, these promotional efforts should be led by the political authorities, leaving delegated authorities with a supporting role, while respecting their 
(prudential) missions. However, in the face of timid political action, delegated authorities concerned about their output legitimacy might decide to move first, going promotional 'by stealth' and without an appropriate underlying change in mandate. Recent changes in some European delegated authorities - most notably the ECB - hint that this change may have begun. This will either result in a green technocratic setting or trigger the reaction of political authorities. At that point, PAs will have to choose between i) disavowing the green pushes of DAs by retaking possession of the green instruments used by DAs and/or limiting their independence; or ii) validating ex post these promotional pushes by backing DAs with new forms of input legitimacy. 
VIII. Bibliography

ACPR. (2020). Scenarios and main assumptions of the ACPR pilot climate exercise. https://acpr.banque-france.fr/en/scenarios-and-main-assumptions-acpr-pilot-climateexercise

Allen, T., Dées, S., Caicedo, M., Chouard, V., Clerc, L., de Gaye, A., Devulder, A., Diot, S., Lisack, N., Pegoraro, F., Rabate, M., Svartzman, R., \& Vernet, L. (2020). Climate-Related Scenarios for Financial Stability Assessment : An Application to France (Working Paper $\left.N^{\circ} 774\right)$. Banque de France. https://www.ssrn.com/abstract=3653131

Ameli, N., Drummond, P., Bisaro, A., Grubb, M., \& Chenet, H. (2020). Climate finance and disclosure for institutional investors: Why transparency is not enough. Climatic Change, 160(4), 565-589. https://doi.org/10.1007/s10584-019-02542-2

Andersson, M., Baccianti, C., \& Morgan, J. (2020). Climate change and the macro economy. ECB Occasional Paper Series, 243. https://data.europa.eu/doi/10.2866/83282

Baer, M. (2020). The Impact of Stranded Fossil Fuel Assets on International Financial Institutions : A financial exposure analysis and implications for European central banks and financial regulators. C-EENRG Working Papers, 2020, pp.1-38. Cambridge Centre for Environment, Energy and Natural Resource Governance, University of Cambridge.

Baker, A. (2013). The New Political Economy of the Macroprudential Ideational Shift. New Political Economy, 18(1), 112-139. https://doi.org/10.1080/13563467.2012.662952

Batten, S. (2018). Climate change and the macro-economy : A critical review (Staff Working Paper $\mathrm{N}^{\circ}$ 706). Bank of England.

BCBS. (2010). Basel III: A global regulatory framework for more resilient banks and banking systems. Basel Committee on Banking Supervision.

BCBS. (2020). Climate-related financial risks : A survey on current initiatives (p. 14). Basel Committee on Banking Supervision.

Beggs, M., \& Deer, L. (2019). Remaking Monetary Policy in China : Markets and Controls, 1998-2008. Springer Singapore. https://doi.org/10.1007/978-981-13-9726-4

Bezemer, D., Ryan-Collins, J., van Lerven, F., \& Zhang, L. (2018). Credit where it's due : A historical, theoretical and empirical review of credit guidance policies in the 20th century. UCL Institute for Innovation and Public Purpose. https://www.ucl.ac.uk/bartlett/publicpurpose/publications/2018/nov/credit-where-its-due

Blinder, A., Ehrmann, M., de Haan, J., \& Jansen, D.-J. (2017). Necessity as the mother of invention : Monetary policy after the crisis. Economic Policy, 32(92), 707-755. https://doi.org/10.1093/epolic/eix013

BoE. (2019). The 2021 biennial exploratory scenario on the financial risks from climate change (p. 33) [Discussion Paper]. Bank of England. https://www.bankofengland.co.uk//media/boe/files/prudential-regulation/supervisory-statement/2019/ss319

Bolton, P., Despres, M., Pereira da Silva, L. A., Samama, F., \& Svartzman, R. (2020). The green swan. Central banking and financial stability in the age of climate change. Bank of International Settlements.

Braun, B., \& Downey, L. (2020). Against Amnesia : Re-Imagining Central Banking (Discussion note $\mathrm{N}^{\circ}$ 2020/1). Council on Economic Policies. https://www.cepweb.org/wpcontent/uploads/2020/01/CEP-DN-Against-Amnesia.-Re-Imagining-Central-Banking.pdf 
Cahen-Fourot, L., Campiglio, E., Godin, A., Kemp-Benedict, E., \& Trsek, S. (2021). Capital stranding cascades : The impact of decarbonisation on productive asset utilisation (Research Papers $\mathrm{N}^{\circ}$ 204). Agence Française de Développement. https://www.afd.fr/en/ressources/capitalstranding-cascades-impact-decarbonisation-productive-asset-utilisation

Caldecott, B. (Éd.). (2018). Stranded Assets and the Environment : Risk, Resilience and Opportunity. Routledge.

Campiglio, E. (2016). Beyond carbon pricing : The role of banking and monetary policy in financing the transition to a low-carbon economy. Ecological Economics, 121, 220-230. https://doi.org/10.1016/j.ecolecon.2015.03.020

Campiglio, E., Dafermos, Y., Monnin, P., Ryan-Collins, J., Schotten, G., \& Tanaka, M. (2018). Climate change challenges for central banks and financial regulators. Nature Climate Change, 8(6), 462-468. https://doi.org/10.1038/s41558-018-0175-0

Campiglio, E., Godin, A., Kemp-Benedict, E., \& Matikainen, S. (2017). The tightening links between financial systems and the low-carbon transition. In P. Arestis \& M. Sawyer (Éds.), Economic policies since the Global Financial Crisis (p. 313-356). Palgrave Macmillan.

Carney, M. (2015). Breaking the Tragedy of the Horizon - climate change and financial stability [Speech given at Lloyd's of London by the Governor of the Bank of England]. Bank of England.

Carney, M. (2016). Remarks on the launch of the Recommendations of the Task Force on Climaterelated Financial Disclosures [Speech]. Bank of England.

Christophers, B. (2017). Climate change and financial instability : Risk disclosure and the problematics of neoliberal governance. Annals of the American Association of Geographers, 107(5), 1108-1127.

Cochrane, J. H. (2020). Central Banks And Climate: A Case Of Mission Creep. Hoover Institution. https://www.hoover.org/research/central-banks-and-climate-case-mission-creep

Dafermos, Y., Gabor, D., Nikolaidi, M., Pawloff, A., \& van Lerven, F. (2020). Decarbonising is easy. Beyond market neutrality in the ECB's corporate QE. New Economics Foundation.

Dankert, J., Doorn, L. van, Reinders, H. J., \& Sleijpen, O. (2018). A Green Supporting Factor-The Right Policy? (SUERF Policy Note No 43 ). SUERF. https://www.suerf.org/policynotes/3473/a-greensupporting-factor-the-right-policy/html

de Boer, N., \& van't Klooster, J. (2020). The ECB, the Courts and the Issue of Democratic Legitimacy After Weiss (SSRN Scholarly Paper ID 3712579). Social Science Research Network. https://papers.ssrn.com/abstract=3712579

Delpla, J., \& Gollier, C. (2019). Pour une Banque Centrale du Carbone (Analyse No 1). Asterion.

Dikau, S., \& Ryan-Collins, J. (2017). Green central banking in emerging market and developing countries. New Economics Foundation.

Dikau, S., \& Volz, U. (2021). Central bank mandates, sustainability objectives and the promotion of green finance. Ecological Economics, 184, 107022. https://doi.org/10.1016/j.ecolecon.2021.107022

Dincer, N. N., \& Eichengreen, B. (2014). Central Bank Transparency and Independence : Updates and New Measures. International Journal of Central Banking, 34.

Dombrovskis, V. (2017). Greening finance for sustainable business [Speech by Vice-President for the Euro and Social Dialogue, Financial Stability and Financial Services]. European Commission. 
D'Orazio, P., \& Popoyan, L. (2019). Fostering green investments and tackling climate-related financial risks: Which role for macroprudential policies? Ecological Economics, 160, 25-37. https://doi.org/10.1016/j.ecolecon.2019.01.029

D'Orazio, P., \& Popoyan, L. (2020). Taking up the climate change challenge : A new perspective on central banking. In LEM Papers Series ( $N^{\circ}$ 2020/19; LEM Papers Series). Laboratory of Economics and Management (LEM), Sant'Anna School of Advanced Studies, Pisa, Italy. https://ideas.repec.org/p/ssa/lemwps/2020-19.html

EBA. (2016). EBA report on SMEs and SME Supporting Factor. European Banking Authority. https://eba.europa.eu/sites/default/documents/files/documents/10180/1359456/602d5c6 1-b501-4df9-8c89-71e32ab1bf84/EBA-Op-201604\%20\%20Report\%20on\%20SMEs\%20and\%20SME\%20supporting\%20factor.pdf?retry=1

EBA. (2019). EBA Action plan on sustainable finance. European Banking Authority. https://www.eba.europa.eu/sites/default/documents/files/document_library/EBA\%20Actio n\%20plan\%20on\%20sustainable\%20finance.pdf

EC. (2018). Action Plan: Financing Sustainable Growth (Communication from the Commission COM/2018/097).

EC. (2019). Call for advice to the European Supervisory Authorities to collect evidence of undue shortterm pressure from the financial sector on corporations. https://ec.europa.eu/info/publications/190201-call-for-advice-to-esas-short-termpressure_en

ECB. (2020). Guide on climate-related and environmental risks (p. 54). European Central Bank. https://www.bankingsupervision.europa.eu/press/pr/date/2020/html/ssm.pr201127 5642 b6e68d.en.html

ECB. (2021, janvier 25). ECB sets up climate change centre. Press Release. https://www.ecb.europa.eu/press/pr/date/2021/html/ecb.pr210125_1 3fc4ebb4c6.en.htm I

Elderson, F. (2018). Let's dance [Keynote speech at the Global Capital Sustainable \& Responsible Markets Forum]. De Nederlandsche Bank.

Consolidated version of the Treaty on the Functioning of the European Union, OJ C 326 (2012).

Fontan, C. (2016). The new behemoth? In D. Gabor \& I. Erturk (Éds.), The Routledge Companion to Banking Regulation and Reform (p. 175-191). Taylor \& Francis.

Fungáčová, Z., Nuutilainen, R., \& Weill, L. (2016). Reserve requirements and the bank lending channel in China. Journal of Macroeconomics, 50, 37-50. https://doi.org/10.1016/j.jmacro.2016.08.007

G30. (2020). Mainstreaming the transition to a net-zero economy. Group of Thirty. https://group30.org/images/uploads/publications/G30_Mainstreaming_the_Transition_to_ a_Net-Zero_Economy.pdf

Goodhart, C. (2010). The Changing Role of Central Banks (SSRN Scholarly Paper ID 1717776). Social Science Research Network. https://doi.org/10.2139/ssrn.1717776

Grosjean, G., Acworth, W., Flachsland, C., \& Marschinski, R. (2016). After monetary policy, climate policy: Is delegation the key to EU ETS reform? Climate Policy, 16(1), 1-25. https://doi.org/10.1080/14693062.2014.965657

Gruin, J. Y. (2016). The social order of Chinese capitalism : Socio-economic uncertainty, communist party rule and economic development, 1990-2000. Economy and Society, 45(1), 24-50. https://doi.org/10.1080/03085147.2016.1143724 
Krogstrup, S., \& Oman, W. (2019). Macroeconomic and financial policies for climate change mitigation: A review of the literature (Working Paper No. 19/185). International Monetary Fund.

Kydland, F. E., \& Prescott, E. C. (1977). Rules rather than discretion: The inconsistency of optimal plans. Journal of political economy, 85(3), 473-491.

Lagarde, C. (2020a). The path forward: The global economy. Washington Post Live 22 July 2020.

Lagarde,

C. (2020b).

IMFC

Statement. https://www.ecb.europa.eu/press/key/date/2020/html/ecb.sp201015 1cb2135e70.en.html

Lagarde, C. (2021). Climate Change And Central Banking.

Mabbett, D., \& Schelkle, W. (2019). Independent or lonely? Central banking in crisis. Review of International Political Economy, 26(3), 436-460. https://doi.org/10.1080/09692290.2018.1554539

Maestre-Andrés, S., Drews, S., \& van den Bergh, J. (2019). Perceived fairness and public acceptability of carbon pricing : A review of the literature. Climate Policy, 19(9), 1186-1204.

Majone, G. (1997). From the Positive to the Regulatory State : Causes and Consequences of Changes in the Mode of Governance. Journal of Public Policy, 17(2), 139-167.

Mason, A., Martindale, W., Heath, A., \& Chatterjee, S. (2016). French Energy Transition Law. Global investor briefing. Principles for Responsible Investments.

Matikainen, S., Campiglio, E., \& Zenghelis, D. (2017). The climate impact of quantitative easing [Policy paper]. Grantham Research Institute on Climate Change and the Environment.

Mazzucato, M. (2016). From market fixing to market-creating : A new framework for innovation policy. Industry and Innovation, 23(2), 140-156. https://doi.org/10.1080/13662716.2016.1146124

McNamara, K. (2002). Rational Fictions: Central Bank Independence and the Social Logic of Delegation. West European Politics, 25(1), 47-76. https://doi.org/10.1080/713601585

Monnet, E. (2018). Controlling Credit : Central Banking and the Planned Economy in Postwar France, 1948-1973. Cambridge University Press.

Monnin, P. (2018). Central banks should reflect climate risks in monetary policy operations (SUERF Policy Notes $N^{\circ}$ 41). SUERF. https://www.suerf.org/policynotes/3325/central-banks-shouldreflect-climate-risks-in-monetary-policy-operations/

NGFS. (2019). A call for action : Climate change as a source of financial risk. Network for Greening the Financial System.

NGFS. (2020). Guide to climate scenario analysis for central banks and supervisors (p. 41) [Technical document]. Network for Greening the Financial System.

Nordhaus, W. D. (1975). The political business cycle. The review of economic studies, 42(2), 169-190.

Oustry, A., Bunyamin, E., Romain, S., \& Pierre-François, W. (2020). Climate-related Risks and Central Banks' Collateral Policy: A Methodological Experiment. In Working papers ( $\mathrm{N}^{\circ} 790$; Working Papers). Banque de France. https://ideas.repec.org/p/bfr/banfra/790.html

PBoC. (2018). Notice of the People's Bank of China on conducting green credit performance evaluation of banking depository financial institutions (PBoC Notice No. 180). People's Bank of China. http://en.pkulaw.cn/display.aspx?cgid=f89b9c0e05312e2ebdfb\&lib=law

Petry, J. (2020a). Financialization with Chinese characteristics? Exchanges, control and capital markets in authoritarian capitalism. Economy and Society, 49(2), 213-238. https://doi.org/10.1080/03085147.2020.1718913 
Petry, J. (2020b). Same same, but different : Varieties of capital markets, Chinese state capitalism and the global financial order. Competition \& Change, 102452942096472. https://doi.org/10.1177/1024529420964723

Rehn, O. (2018). Climate change and green finance [Keynote speech at the Finnish Climate Summit]. Bank of Finland.

Roncoroni, A., Battiston, S., Escobar Farfàn, L. O. L., \& Martinez Jaramillo, S. (2021). Climate Risk and Financial Stability in the Network of Banks and Investment Funds (SSRN Scholarly Paper ID 3356459). Social Science Research Network. https://doi.org/10.2139/ssrn.3356459

Scharpf, F. W. (1999). Governing in Europe : Effective and democratic? Oxford University Press.

Schmidt, V. A. (2013). Democracy and Legitimacy in the European Union Revisited : Input, Output and 'Throughput'. Political Studies, 61(1), 2-22.

Schmidt, V. A. (2016). Reinterpreting the rules 'by stealth' in times of crisis : A discursive institutionalist analysis of the European Central Bank and the European Commission. West European Politics, 39(5), 1032-1052. https://doi.org/10.1080/01402382.2016.1186389

Schnabel, I. (2020). When markets fail - the need for collective action in tackling climate change [Speech by Isabel Schnabel, Member of the Executive Board of the ECB, at the European Sustainable Finance Summit]. European Central Bank. https://www.ecb.europa.eu/press/key/date/2020/html/ecb.sp200928_1 268b0b672f.en.ht $\mathrm{ml}$

Schoenmaker, D. (2021). Greening monetary policy. Climate Policy, 21(4), 581-592. https://doi.org/10.1080/14693062.2020.1868392

Scialom, L. (2019). La fascination de l'ogre, ou, Comment desserrer l'étau de la finance. Fayard.

Solana, J. (2019). The Power of the Eurosystem to Promote Environmental Protection. European Business Law Review, 30(4). https://kluwerlawonline.com/journalarticle/European+Business+Law+Review/30.4/EULR201 9024

TCFD. (2017). Recommendations of the Task Force on Climate-related Financial Disclosure.

Tsebelis, G. (2002). Veto players : How political institutions work. Princeton University Press.

UNFCCC. (2016). Report of the Conference of the Parties on its twenty-first session, held in Paris from 30 November to 13 December 2015. Addendum. Part two : Action taken by the Conference of the Parties at its twenty-first session. (FCCC/CP/2015/10/Add.1). United Nations Framework Convention on Climate Change.

van der Ploeg, F., \& Rezai, A. (2020). Stranded Assets in the Transition to a Carbon-Free Economy. Annual Review of Resource Economics, 12, 281-298.

van't Klooster, J. (2021). The ECB's conundrum and 21st century monetary policy: How European monetary policy can be green, social and democratic [Preprint]. SocArXiv. https://doi.org/10.31235/osf.io/f25td

van't Klooster, J., \& Fontan, C. (2020). The Myth of Market Neutrality : A Comparative Study of the European Central Bank's and the Swiss National Bank's Corporate Security Purchases. New Political Economy, 25(6), 865-879. https://doi.org/10.1080/13563467.2019.1657077

Vermeulen, R., Schets, E., Lohuis, M., Kölbl, B., Jansen, D.-J., \& Heeringa, W. (2019). The Heat is on : A framework for measuring financial stress under disruptive energy transition scenarios. De Nederlandsche Bank. 
Wainwright, J., \& Mann, G. (2018). Climate Leviathan : A political theory of our planetary future. Verso Books.

Wang, Y. (2015). The rise of the 'shareholding state' : Financialization of economic management in China. Socio-Economic Review, 13(3), 603-625. https://doi.org/10.1093/ser/mwv016

Weidmann, J. (2020). Combating climate change - What central banks can and cannot do [Speech at the European Banking Congress]. Deutsche Bundesbank.

World Bank. (2020). State and trends of carbon pricing 2020. World Bank.

Zheng, L. (2018). The Macro Prudential Assessment Framework of China. Centre for International Governance Innovation. 